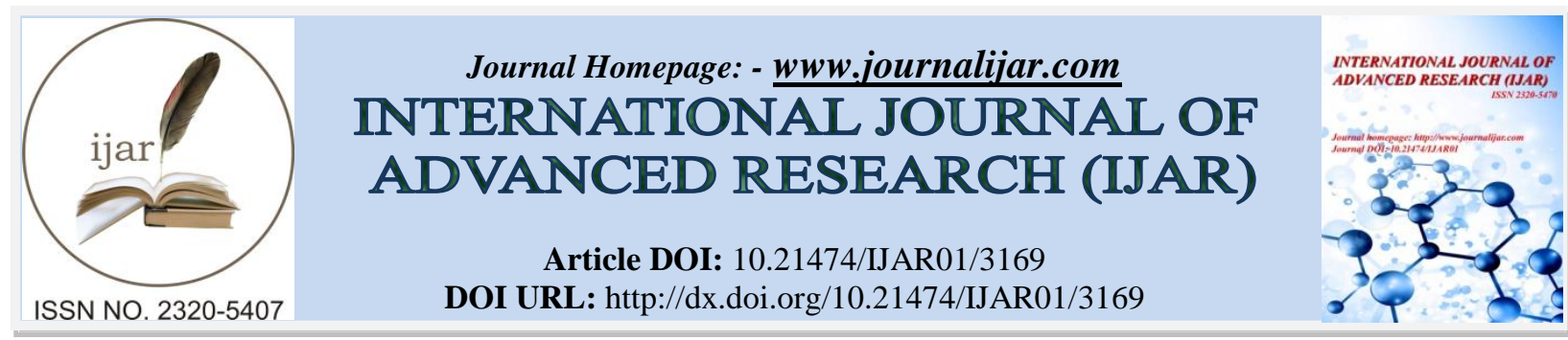

RESEARCH ARTICLE

\title{
PROGNOSTIC SIGNIFICANCE OF IMMUNOHISTOCHEMISTRY AND PROLIFERATIVE ACTIVITY IN COLORECTAL CANCER USING SURVIVIN, COX2, S PHASE FRACTION AND DNA PLOIDY.
}

\author{
Walid S. H. Elsayed ${ }^{1}$, Samah S. Elbasateeny ${ }^{1 \%}$, Rasha S. H. Elsayed ${ }^{2}$, Ibtsam S. Harera ${ }^{2}$ and Rehab S Abdul- \\ Maksoud $^{3}$ \\ 1. Pathology Department, Faculty of Medicine, Zagazig University, Egypt. \\ 2. Surgery Department, Faculty of Medicine, Zagazig University, Egypt \\ 3. Medical Biochemistry Department, Faculty of medicine, Zagazig University, Egypt.
}

\section{Manuscript Info}

(..........................

Manuscript History

Received: 05 December 2016

Final Accepted: 08 January 2017

Published: February 2017

Key words:-

colorectal cancer,

Immunohistochemistry, Prognostic

factor, S phase fraction, DNA ploidy.

\section{Abstract}

Background:- Aggressiveness of neoplasm may be linked to the biological characteristic of tumor cells, represented by the level of expression of specific molecular markers. Aim: was to examine the coexpression of survivin, COX-2, DNA ploidy and S phase fraction (SPF) in colorectal carcinomas and assess its prognostic value. Material and Methods:- neoplastic tissue from 100 patients with primary non treated colorectal adenocarcinomas were assessed by immunohistochemistry and flow cytometry. Statistical analysis evaluated the correlation of marker expression with clinicopathological variables and with the expression of other markers. Results:- Survivin and COX-2 cytoplasmic immunoreactivity was detected in $65 \%$ and $73 \%$ respectively of the studied adenocarcinomas. Flow cytometry revealed that $62 \%$ of carcinomas were aneupliod and $47 \%$ had high SPF. COX2, DNA aneuploidy and high SPF showed significantly association with lymph nodes $(\mathrm{LN})$ involvement and Dukes' stage $(\mathrm{P}=0.04, \mathrm{P}=0.02$ and 0.03 , respectively for $\mathrm{LN}$ and $\mathrm{P}=0.03, \mathrm{P}=0.01$ and 0.04 , respectively for Dukes' stage). DNA aneuploidy was positively associated with histological grade $(\mathrm{P}=0.03)$. High SPF and DNA aneuploidy were positively associated with tumor localization $(\mathrm{P}=0.03$ for both). COX-2 displayed positive association with survivin expression and with recurrence $(\mathrm{P}=0.04$ and $\mathrm{P}=0.02$ respectively). High SPF significantly associated with survivin, COX-2 and DNA ploidy ( $\mathrm{P}=0.005, \mathrm{P}=0.004$ and 0.02 , respectively). The expression of more markers by each carcinoma was positively correlated with LN involvement $(\mathrm{P}=0.04)$ and advanced stage $(\mathrm{P}=0.001)$. Conclusions: Our analysis demonstrate that the score of markers co-expression correlates significantly with the poor prognosis of patients with colorectal adenocarcinomas.

Copy Right, IJAR, 2017,. All rights reserved.

\section{Introduction:-}

Colorectal malignancy is included as one from the most common malignancy around the world, and is regarded as one of the major reasons of cancer related mortality [1]. The growth and development of colorectal carcinoma 
proceeds via sequences of multistep genetic alterations including the stimulation of caner causing genes and damage of tumor suppressor genes. The majority of colorectal carcinomas develop on top of dysplasia of benign adenomas that progressively enlarge and transform into a villous adenomas. The continuous gathering of genetic changes (e.g., DCC, ras ,p53, and DCC) drive the evolution of normal colonic and rectal epithelium to adenoma as well as the transformation to dysplasia and malignant adenocarcinoma [2].

Despite the progresses in surgical techniques and adjuvant chemotherapeutic regimens have decreased the earlier elevated local recurrence rates of colorectal cancer and have provided patients with better survival [3], many patients presented with local recurrences or distant metastasis following seemingly curative surgical operations resulting in low survival [4]. Evaluation of prognostic molecular factors that is linked to a certain prognostic outcome would as a result, be helpful for detection of cases who are probable to improve with adjuvant treatments, resulting in better prognosis [5].

Survivin is considered to be one of the members of the group of inhibitor of apoptosis protein (IAP). It is involved in controlling the physiological development of embryonic cells and monitoring the cycle of the cell, with double jobs that block apoptosis and stimulates cellular multiplying. Overexpression of survivin stops apoptosis via several mechanisms, which is favorable to the divisions of abnormal cell and promotes neoplastic transformation [6-8].

The fetal tissues and majority of neoplastic tissues show expression of survivin while; negative expression is detected in normal mature tissues. Survivin displays highly discriminating positive expression in malignant neoplasms, and its expression is associated with the high cellular proliferative activity, the resistance of neoplasms to cancer therapy, high metastatic capability of tumors, high recurrence potential, and the unfavorable outcome of patients. As a result, survivin had considered to be an important diagnostic marker for wide variety of tumors and a molecular target for successful cancer therapy [9-11].

Cyclooxygenases are important enzymes that catalyze the cellular alteration of arachidonic acid to prostaglandins. In humans, two types of cyclooxygenase enzymes have been detected, the constitutive form COX-1 and the inducible form COX-2 [12]. The upregulation of COX-2 in transformed tissues and in several types of malignancy is proved by epidemiological and experimental studies, and as a result, it is essential in neoplastic transformations. It is approved that expression of COX-2 is implicated in differentiation, angiogenesis and apoptosis of the neoplasms. $[12,13]$ Many researches have revealed that the expression of COX- 2 occurs at high levels in $80-90 \%$ of the adenocarcinomas of colon and rectum. [14, 15], and selective suppression of COX-2 decrease tumourigenesis of the colon and rectum in various carcinogenesis models [16].

DNA ploidy and S-phase fraction (SPF) measured flow cytometry, are significant and independent prognostic factors in patients suffering from colorectal carcinoma [17]. Most investigators [18-20] agree that there is association between the presences of aneuploid cell populations by flow cytometry and unfavorable outcome.

We aimed to study the co-expression of immunohistochemical staining of survivin and COX-2 proteins, DNA ploidy and the proliferative activity using SPF in colorectal carcinomas and their correlation with patient's clinicopathological characteristics to assess their prognostic value.

\section{Materials and Methods:-}

Patients and Tissue Samples:-

Our research was done at the Departments of Pathology and Surgery, Faculty of Medicine, University of Zagazig in the period from January 2012 to May 2016. One hundred neoplasms were obtained from patients with primary sporadic colorectal carcinoma. The age, the sex, the location of the tumor, Dukes' stage and other clinicopathological variables were gotten from surgical and pathological sheets. All of the cases had no history of hereditary colon cancer syndromes. There was no chemotherapy or radiation given to the cases before the operation; but after surgery, patients with stage III tumor and stage IV tumor received chemotherapy without any radiation for both colon and rectal cancer. The committee of ethics of Zagazig University approved this research and all patients gave a consent of agreement prior to their inclusion in the research. All samples were fixed with formalin and implanted into paraffin, the blocks were sectioned at 3- microns and stained with ordinary H\&E stain to confirm the diagnosis and grade the neoplasms. 


\section{Immunohistochemical Staining:-}

The Sections of 3- $\mu \mathrm{m}$ thick were cut from paraffin blocks of the collected colorectal neoplasms. Sections were deparaffinized and rehydrated and deposited in $0.5 \%$ hydrogen peroxide in methanol for 10 min to stop endogenous peroxidase activity. Antigen retrieval was achieved by keeping in $0.01 \mathrm{M}$ citrate buffer $(\mathrm{pH}$ 6.0) for 5 minutes in a pressure cooker. The primary antibodies were added to the sections at room temperature for $60 \mathrm{~min}$. The strept avidin-biotin-peroxidase complex technique was applied for antibodies aganist survivin (monoclonal anti-survivin antibody, Clone 12C4, Code M3624, Santa Cruz Biotechnology, Santa Cruz, California, USA, Dilution 1:100) and aganist COX-2 (rabbit polyclonal Anti- COX-2, RB-9072-R1; Lab Vision corporation, Neo Markers, Dilution $1: 200$ ), by utilizing diaminobenzidine (DAB) as the chromogen. Negative control slides in the lack of primary antibody were considered for each staining. A colon carcinoma, which intensely expressed survivin mRNA by RTPCR [21], was considered as a positive control. As a positive control for COX-2, we used a normal kidney tissue or an intestinal metaplasia.

\section{Scoring Criteria for survivin:-}

According to previously described reports [22,23], the mean proportion of positive carcinoma cells in at least five fields using high power was established and allocated to one of five groups: (1) $0,<5 \%$; (2) $1,5 \%$ to $25 \%$; (3) 2 , $25 \%$ to $50 \%$; (4) $3,50 \%$ to $75 \%$; and (5) $4,>75 \%$. The intensity of survivin immunostaining was recorded as (1) weak, $1+,(2)$ moderate, $2+$; and (3) intense, $3+$. The proportion of positive tumor cells and staining intensity were multiplied to get a final score for each neoplasm. In neoplasm showing heterogeneous immunostaining, the predominant staining pattern was evaluated for scoring. Neoplasms having final scores $<1$ were described as negative; the rest of neoplasms were stated as positive.

\section{Scoring Criteria for COX-2:-}

For COX-2 evaluation [24], intensity of immunostaining was scored as 0 (negative), 1 (weak), 2 (medium), and 3 (strong). Extent of immunostaining was assessed as $0(0 \%), 1(1-25 \%), 2(26-50 \%), 3(51-75 \%)$, and 4 (76-100\%) depending on the proportions of areas with positive immunostaining in relation to the entire tumor area. The sum of the intensity and extent score was used as the final staining score $(0-7)$ for COX-2. Neoplasms were recorded as positive when having a final immunostaining score $>2$.

\section{For flow cytometry:-}

Two to four $50 \mu \mathrm{m}$ sections for DNA FCM were located into glass tubes. The neoplastic tissue for FCM was first deparaffinized by using two bathes of toluene (10 minutes, each), Rehydration in gradually decreasing concentrations of alcohols for 10 minutes in each grade. At the end, the tissue was washed in refined water. The tissue was then milled with blades and yielded to $0.5 \%$ pepsin digestion for half an hour. Then, the cells were taken with a syringe and filtered with using a 50- $\mu \mathrm{m}$ filter mesh and put on a two layer sucrose cushion to remove the debris. ANAse and propidium iodide were put for half an hour prior to the process. The sample then analyzed with a flow cytometer equipped with an argon laser light beam (wavelength $488 \mathrm{~nm}$.) [25].

\section{DNA Quantitation and S- phase fraction Estimation:-}

The machine computes the DNA index (DI), coefficient of variation (CV) and cell cycle indices including S-phase fraction (SPF). For each slide, 20 lymphocytes were used as an internal diploid DNA content standard for that slide. At least 200 nuclei which is non-overlapping from each slide were then measured. Peak statistics are depended on employer distinction of the histogram. The CV of each peak is measured in the standard deviation of demarcated peak divided by the mean. Histograms were considered as uninterpretable for ploidy if the CV for the DNA diploid G0/G1 peak was $>8$. The histograms were regarded as diploid when a solitary peak present at the diploid position (DI range $0.90-1.10$ ) and less than $15 \%$ of cells were present at the tetraploid position. If an extra distinct peak was detected, the lesion will be categorized into one of the 5 non-diploid groups based on DI. Thus the lesion will be regarded as DNA hypodiploid for DI $<0.9$, hyperdiploid for DI in the range of 1.1-1.90 tetraploid for the DI in the range of 1.9-2.10 and hypertetraploid for DI more than 2.10.If more than one non-diploid peak was detected, the lesion will be categorized as multiploid. For tetraploid lesion, the extra peak should be detected in the teraploid region and should have $\geq 15 \%$ of cells in the presence of identifiable G2/M peak. The aneuploidy term is used to designate hypodiploid, hyperdiploid and hypertetraploid subgroups of nondiploid tumors as single category. According to Taylor and associates (26), S-phase $>5 \%$ was considered hyperproliferative and $\leq 5 \%$ was considered as normoproliferative. 


\section{Statistical Analysis:-}

Analysis of the result was done by using SPSS, version 10.0 (SPSS, Inc., Chicago, IL, USA). Categorical data were expressed as frequencies (and percentages) and continuous data were expressed as the mean \pm standard deviation. The chi-square test was used to assess any possible association among survivin immunoexpression, COX- 2 immunoexpression, ploidy of DNA and the fraction of $\mathrm{S}$ phase and the clinicopathological variables. Statistical significance was reflected for $\mathrm{P}$ values $<0.05$.

\section{Results:-}

\section{Clinicopathological results:-}

The mean age of the studied 100 colorectal adenocarcinomas patients at initial surgery was $59 \pm 10$ years, rang (4075 years), $70 \%$ were males and $30 \%$ were female, $31 \%$ were proximal tumors and $69 \%$ were distal tumors. All colorectal carcinoma patients' clinicpathological variables are outlined in Table 1.

Table 1:- Clinicopathological characteristics of 100 patients with colorectal cancer.

\begin{tabular}{|c|c|}
\hline Characteristic & No. of patients (\%) \\
\hline $\begin{array}{c}\text { Age (years) } \\
\text { Mean } \pm \text { SD } \\
\text { Median (Range) }\end{array}$ & $\begin{array}{c}59 \pm 10 \\
58(40-75) \\
\end{array}$ \\
\hline $\begin{array}{c}\text { Age } \\
<65 \text { years } \\
\geq 65 \text { years }\end{array}$ & $\begin{array}{l}49(49 \%) \\
51(51 \%)\end{array}$ \\
\hline $\begin{array}{c}\text { Sex } \\
\text { Male } \\
\text { Female }\end{array}$ & $\begin{array}{l}70(70 \%) \\
30(30 \%)\end{array}$ \\
\hline $\begin{array}{c}\text { LN involvement } \\
\text { No } \\
\text { Yes }\end{array}$ & $\begin{array}{l}55(55 \%) \\
45(45 \%)\end{array}$ \\
\hline $\begin{array}{c}\text { Histolopathological grade } \\
\text { I,II } \\
\text { III }\end{array}$ & $\begin{array}{l}71(71 \%) \\
29(29 \%)\end{array}$ \\
\hline $\begin{array}{c}\text { Distant metastasis } \\
\text { No } \\
\text { Yes }\end{array}$ & $\begin{array}{l}68(68 \%) \\
32(32 \%)\end{array}$ \\
\hline $\begin{array}{c}\text { Dukes' stage } \\
\text { A,B } \\
\text { C, D }\end{array}$ & $\begin{array}{l}47(47 \%) \\
53(53 \%)\end{array}$ \\
\hline $\begin{array}{l}\text { Localization } \\
\text { Proximal tumors } \\
\text { Distal tumors }\end{array}$ & $\begin{array}{l}31(31 \%) \\
69(69 \%)\end{array}$ \\
\hline $\begin{array}{c}\text { Recurrence } \\
\text { Yes } \\
\text { No } \\
\text { Unknown }\end{array}$ & $\begin{array}{l}36(36 \%) \\
49(49 \%) \\
15(15 \%)\end{array}$ \\
\hline
\end{tabular}

Immunohistichemical Expression of Survivin in Colorectal Carcinomas:-

Survivin immunoreactivity was expressed mainly in the cytoplasm of adenocarcinomas cells but minimal nuclear reactivity was also seen in a few cases. In contrast, no survivin expression was identified in either the tumor stromal cells or in the nearby normal mucosa (Fig.1). Based on final scores, $65(65 \%)$ colorectal carcinomas were considered as Survivin positive and 35(35\%) colorectal carcinomas were described as Survivin-negative (Table 2). 


\section{Immunohistichemical Expression of COX-2 in Colorectal Carcinomas:-}

Immunohistochemical staining of the colorectal cancer specimens revealed that COX-2 expression was restricted to the carcinoma cells and was not demonstrable in the stromal compartment of the cancers. Immunostaining pattern of COX-2 within the tumors was mainly in the cytoplasm, adjacent non neoplastic colonic mucosa was negative for for COX-2 immunoexpression (Fig. 2). 73 of 100 (73\%) colorectal carcinomas analyzed, revealed expression of COX-2 immunoreactivity (Table 2).

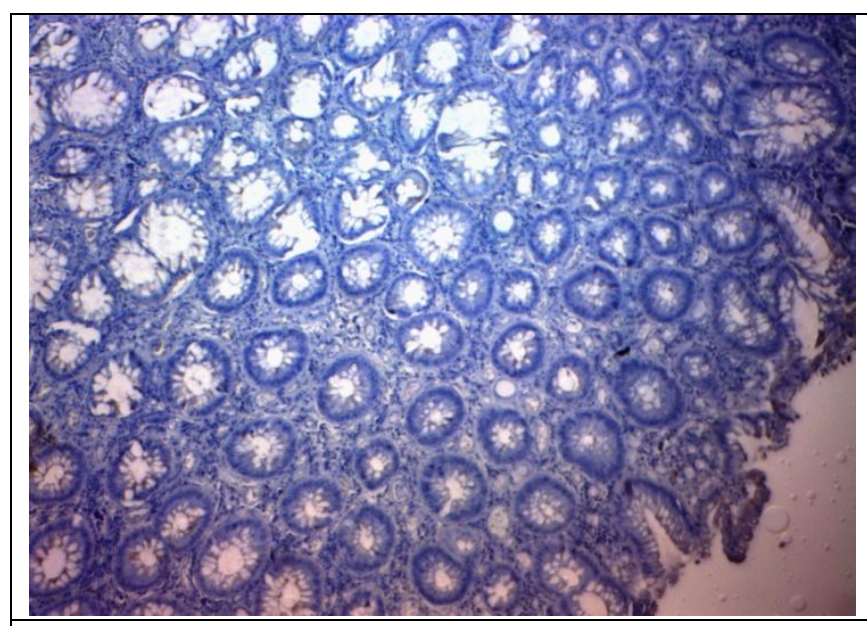

(a)

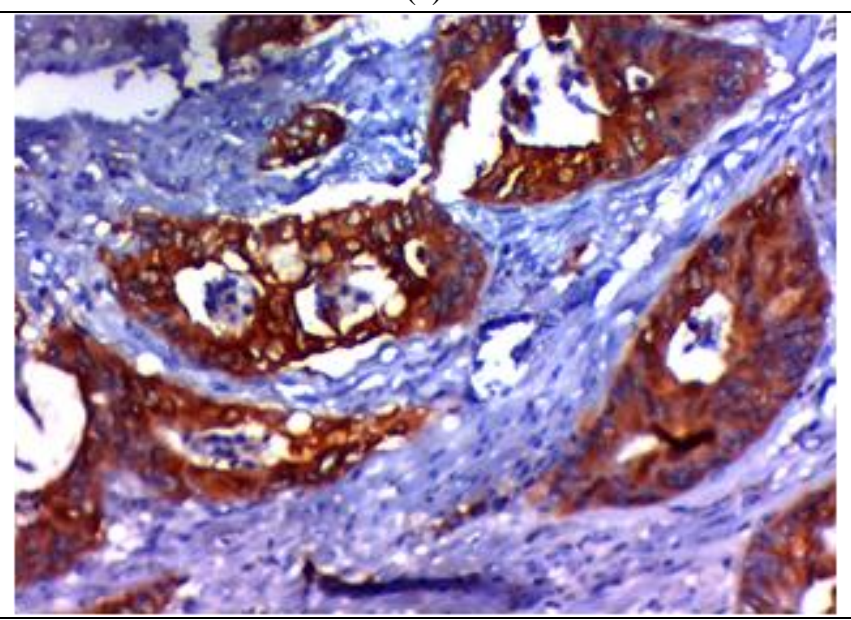

(c)

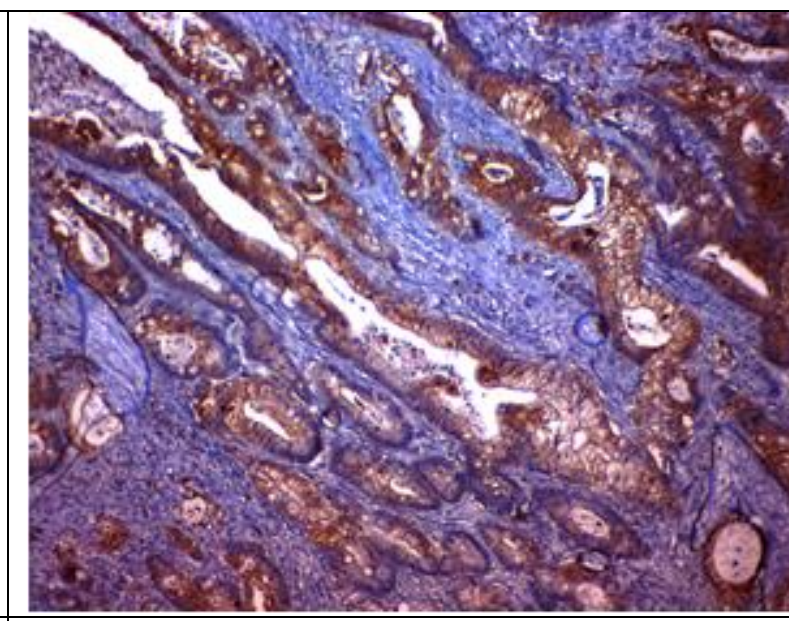

(b)

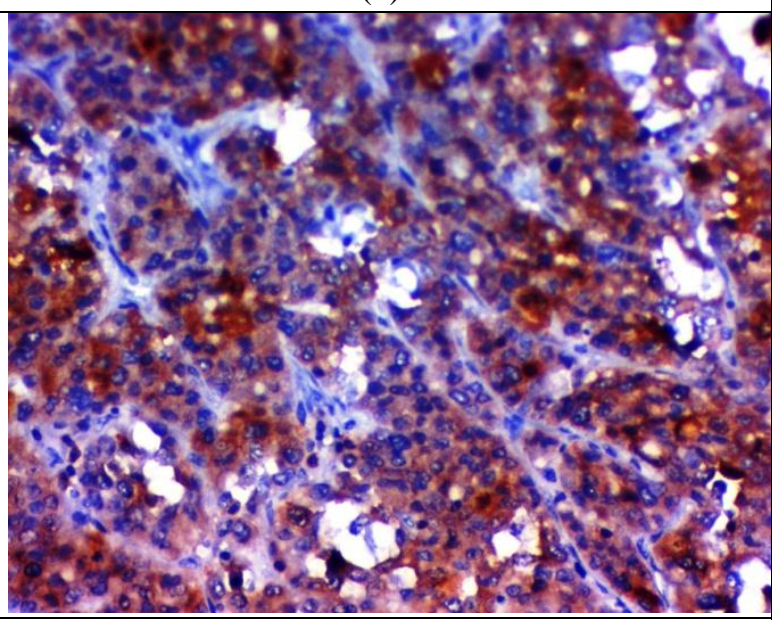

(d)

Fig. 1:- Representative samples of survivin immunoexpression in colorectal carcinoma. (a) Normal colonic mucosa displayed no expression of survivin. (x 200) (b) Colorectal carcinoma GI-II showed diffuse moderate survivin immunoreactivity (x 200). (c) Colorectal carcinoma G II showed diffuse intense survivin immunoreactivity (x 400). (d) Colorectal carcinoma GIII showed diffuse intense survivin immunoreactivity ( $\mathrm{x}$ 400). 


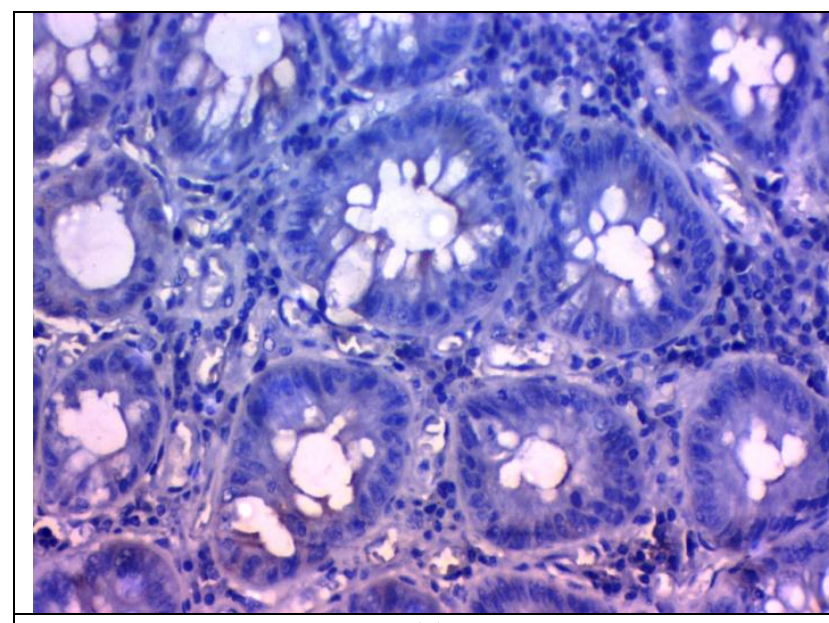

(a)

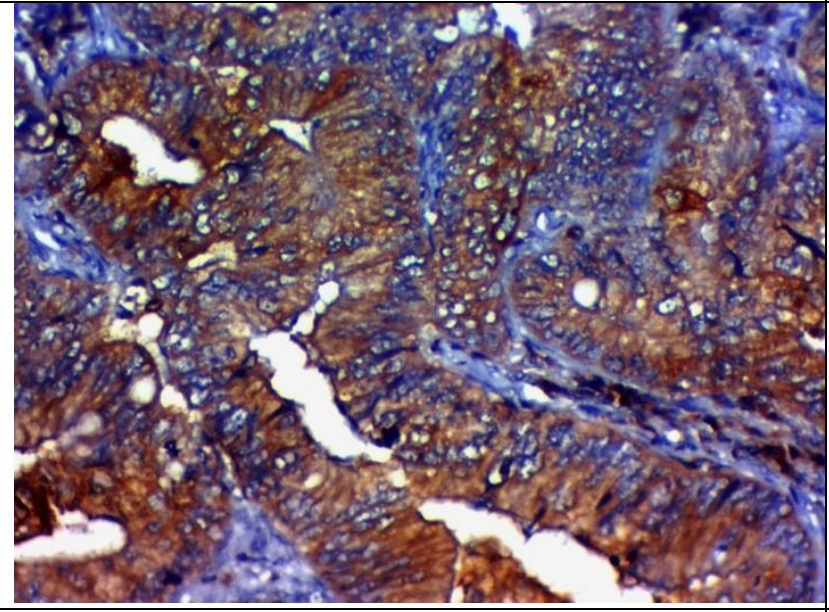

(c)

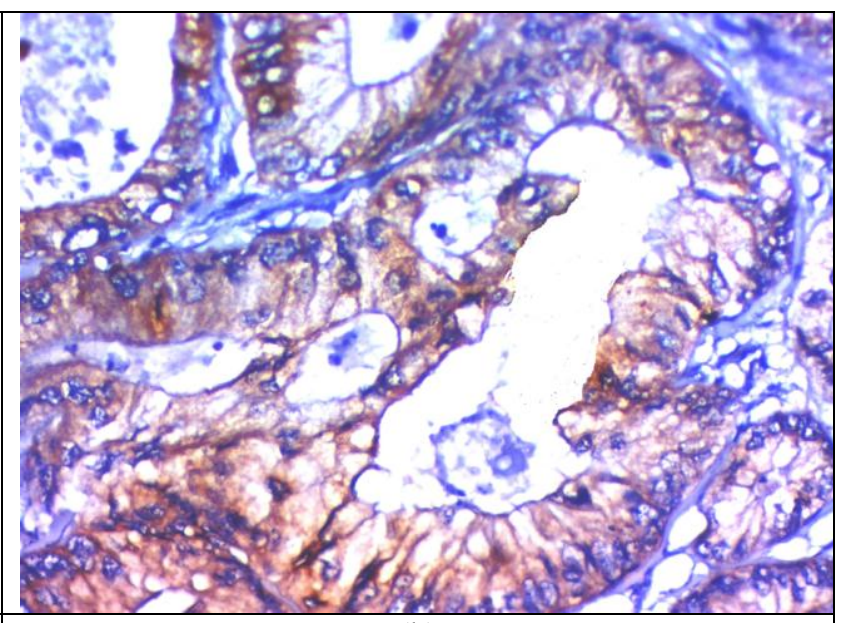

(b)

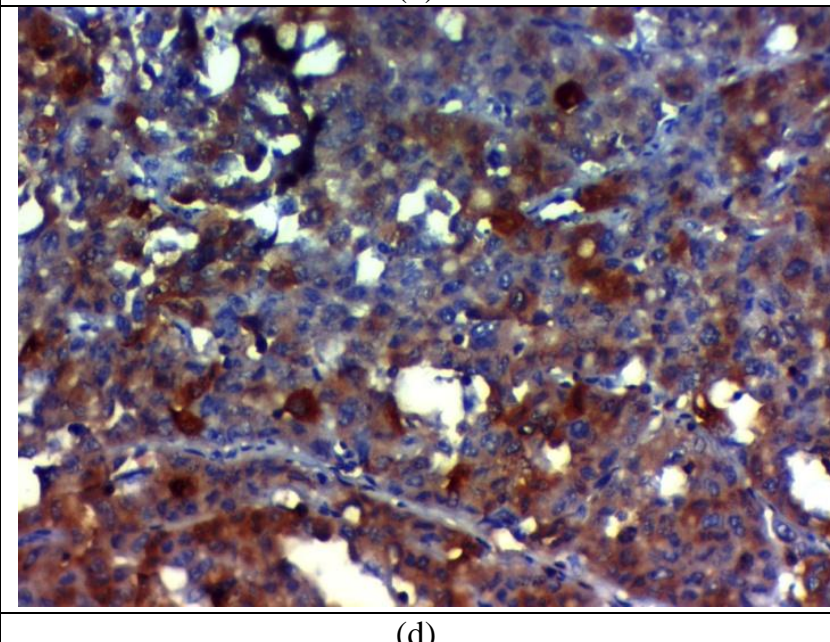

(d)

Fig. 2:- Representative samples of COX2 immunoexpression in colorectal carcinoma. (a) Normal colonic mucosa exhibited negative expression of COX-2. (d) Colorectal carcinoma GII displayed weak immunohistochemical staining for COX-2. (d) Colorectal carcinoma GII displayed strong immunohistochemical staining for COX-2. (d) Colorectal carcinoma GIII displayed moderate to strong immunohistochemical staining for COX-2. (X400)

Flow cytometric analysis:-

Of the 100 carcinomas examined, $38(38 \%)$ were designated as DNA diploid and $62(62 \%)$ as DNA aneuploidy (Table 2). Aneuploid tumors had mean DI of 1.75 (range, 0.93-3.21). These colorectal cancers had SPF ranged from $7.5 \%$ to $45.6 \%$. The median SPF was assessed to be $18.3 \%$. There was a significantly higher SPF in DNA-aneuploid tumors when compared with DNA-diploid tumors $(29.3 \%, 16.6 \%$, respectively, $\mathrm{P}=0.001)$ (Fig. 3). Depending on the median value of SPF as point of cut-off, neoplasms were consequently separated into high ( $>18.3)$ and low ( $\leq$ 18.3) SPF neoplasms (Table 2). 


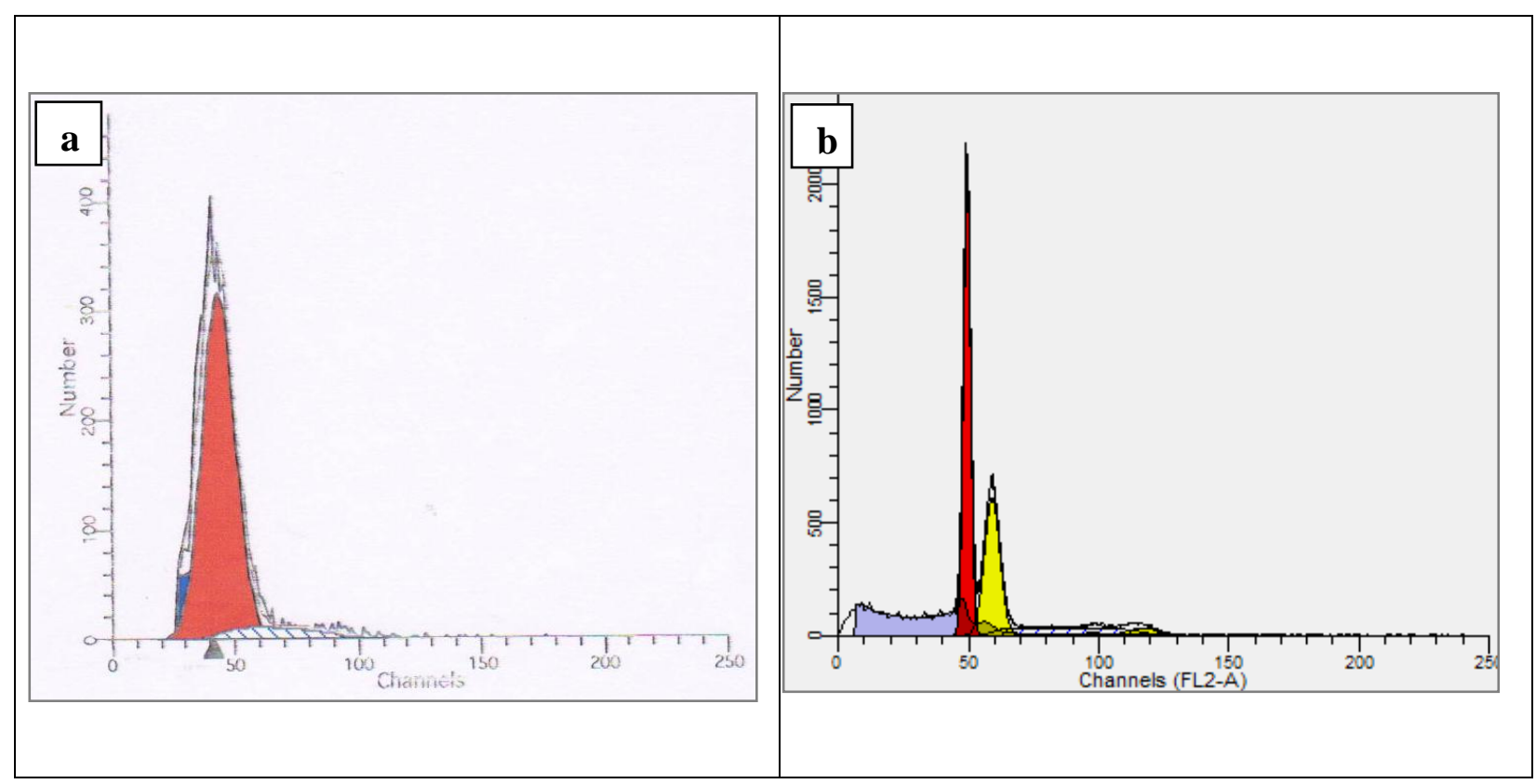

Fig. 3:- Flow cytometry DNA histogram of colorectal cancer showing diploid peak (DI=1.01) and the SPF was (9.98) (a) and diploid \& aneuploid peaks (DI=1.01\&1.77) and the SPF was (19.86) (b).

Table 2:- Patients Distribution depending on the result of immunohistochemical expressions and flow cytometry.

\begin{tabular}{|c|c|}
\hline Marker & No of patients (\%) \\
\hline Survivin & $35(35 \%)$ \\
Negative & $65(65 \%)$ \\
Positive & $27(27 \%)$ \\
\hline COX-2 & $73(73 \%)$ \\
Negative & \\
Positive & $38(38 \%)$ \\
\hline DNA ploidy & $62(62 \%)$ \\
Diploid & \\
Aneuploid & $53(53 \%)$ \\
\hline SPF & $47(47 \%)$ \\
\hline
\end{tabular}

Association of survivin expression, COX-2 expression, DNA aneuploidy and high SPF with tumor clinicopathological variables and markers expressions:-

The result of markers expression was investigated in associations with the following variables: patient's gender, age, lymph nodes involvement, distant metastasis, Dukes'stage, histological grade, localization and recurrence as well as expression with the other markers examined (Table 3). COX-2, DNA aneuploidy and high SPF showed statistically significant association with lymph nodes involvement and Dukes' stage $(\mathrm{P}=0.04, \mathrm{P}=0.02$ and 0.03 , respectively for $\mathrm{LN}$ involvement and $\mathrm{P}=0.03, \mathrm{P}=0.01$ and 0.04 , respectively for Dukes' stage). DNA aneuploidy was positively associated with histological grade $(\mathrm{P}=0.03)$. High $\mathrm{S}$ phase and DNA aneuploidy were also positively associated with tumor localization $(\mathrm{P}=0.031$ and $\mathrm{P}=0.036$, respectively). COX -2 displayed also positive association with tumor recurrence $(\mathrm{P}=0.021)$. No association was observed with other clinicopathological variables. Between marker expressing tissues, high $\mathrm{S}$ phase showed statistically significant association with survivin, COX-2 and DNA ploidy $(\mathrm{P}=0.005, \mathrm{P}=0.004$ and 0.02 , respectively). In addition, there was association between survivin expression with COX-2 $(\mathrm{P}=0.04)$. 
Table 3:- Marker expressing colorectal carcinomas in associations with clinicopathological variables and coexpression with other markers

\begin{tabular}{|c|c|c|c|c|}
\hline & Survivin & $\mathrm{COX}-2$ & DNA aneuploidy & $\begin{array}{l}\text { High SPF } \\
(>18.3 \%)\end{array}$ \\
\hline $\begin{array}{l}\text { Gender } \\
\text { Male } \\
\text { Female }\end{array}$ & $\begin{array}{l}45(64.2 \%) \\
20(66.6 \%) \\
\mathrm{P}=0.9\end{array}$ & $\begin{array}{l}52(74.2 \%) \\
21(70 \%) \\
\mathrm{P}=0.8\end{array}$ & $\begin{array}{l}44(62.8 \%) \\
18(60 \%) \\
\mathrm{P}=0.8\end{array}$ & $\begin{array}{l}31(44.2 \%) \\
16(53.3 \%) \\
\mathrm{P}=0.6\end{array}$ \\
\hline $\begin{array}{l}\text { Age } \\
<65 \text { years } \\
\geq 65 \text { years }\end{array}$ & $\begin{array}{l}36(73.4 \%) \\
29(56.8) \\
\mathrm{P}=0.4\end{array}$ & $\begin{array}{l}35(71.4 \%) \\
38(74.5 \%) \\
\mathrm{P}=0.8\end{array}$ & $\begin{array}{l}28(57.1 \%) \\
34(66.6 \%) \\
\mathrm{P}=0.6\end{array}$ & $\begin{array}{l}20(40.8 \%) \\
27(52.9 \%) \\
\mathrm{P}=0.4\end{array}$ \\
\hline $\begin{array}{l}\text { LN involvement } \\
\text { No } \\
\text { Yes }\end{array}$ & $\begin{array}{l}30(54.5 \%) \\
35(77.7 \%) \\
\mathrm{P}=0.2\end{array}$ & $\begin{array}{l}51(92.7 \%) \\
22(48.8 \%) \\
\mathrm{P}=0.04\end{array}$ & $\begin{array}{l}45(81.8 \%) \\
17(37.7 \%) \\
\mathrm{P}=0.02\end{array}$ & $\begin{array}{l}17(30.9 \%) \\
30(66.6 \%) \\
P=0.03\end{array}$ \\
\hline $\begin{array}{l}\text { Distant metastasis } \\
\text { No } \\
\text { Yes }\end{array}$ & $\begin{array}{l}46(67.6 \%) \\
19(59.3 \%) \\
\mathrm{P}=0.7\end{array}$ & $\begin{array}{l}51(75 \%) \\
22(68.7 \%) \\
\mathrm{P}=0.7\end{array}$ & $\begin{array}{l}38(55.8 \%) \\
24(75 \%) \\
\mathrm{P}=0.3\end{array}$ & $\begin{array}{l}29(42.6 \%) \\
18(56.2 \%) \\
\mathrm{P}=0.4\end{array}$ \\
\hline $\begin{array}{l}\text { Dukes' stage } \\
\text { A, B } \\
\text { C, D }\end{array}$ & $\begin{array}{l}29(61.7 \%) \\
36(67.9 \%) \\
\mathrm{P}=0.7\end{array}$ & $\begin{array}{l}46(97.8 \%) \\
27(50.9 \%) \\
\mathrm{P}=0.03\end{array}$ & $\begin{array}{l}17(36.1 \%) \\
45(84.9 \%) \\
\mathrm{P}=0.01\end{array}$ & $\begin{array}{l}14(29.7 \%) \\
33(62.2 \%) \\
\mathrm{P}=0.04\end{array}$ \\
\hline $\begin{array}{l}\text { Histological grade } \\
\text { I, II } \\
\text { III }\end{array}$ & $\begin{array}{l}47(66.1 \%) \\
18(62 \%) \\
\mathrm{P}=0.8\end{array}$ & $\begin{array}{l}53(74.6 \%) \\
20(68.9 \%) \\
\mathrm{P}=0.8\end{array}$ & $\begin{array}{l}53(74.3 \%) \\
9(31 \%) \\
\mathrm{P}=0.03\end{array}$ & $\begin{array}{l}32(45 \%) \\
15(51.7 \%) \\
\mathrm{P}=0.7\end{array}$ \\
\hline $\begin{array}{l}\text { Localization } \\
\text { Proximal tumors } \\
\text { Distal tumors }\end{array}$ & $\begin{array}{l}20(64.5 \%) \\
45(65.2 \%) \\
\mathrm{P}=0.9\end{array}$ & $\begin{array}{l}21(67.7 \%) \\
52(75.3 \%) \\
\mathrm{P}=0.7\end{array}$ & $\begin{array}{l}10(32.2 \%) \\
52(75.3 \%) \\
\mathrm{P}=0.03\end{array}$ & $\begin{array}{l}7(22.5 \%) \\
40(57.9 \%) \\
P=0.03\end{array}$ \\
\hline $\begin{array}{l}\text { Recurrence } \\
\text { Yes } \\
\text { No } \\
\text { Unknown }\end{array}$ & $\begin{array}{l}22(61.1 \%) \\
39(79.5 \%) \\
4(26.6 \%) \\
P=0.1\end{array}$ & $\begin{array}{l}32(88.8 \%) \\
39(79.5 \%) \\
2(13.3 \%) \\
\mathrm{P}=0.02\end{array}$ & $\begin{array}{c}25(69.4 \%) \\
32(65.3 \%) \\
5(33.3 \%) \\
\mathrm{P}=0.4\end{array}$ & $\begin{array}{l}16(44.4 \%) \\
28(57.1 \%) \\
3(20 \%) \\
P=0.2\end{array}$ \\
\hline $\begin{array}{l}\text { Survivin } \\
\text { Negative } \\
\text { Positive }\end{array}$ & $\begin{array}{l}0(0 \%) \\
65(100 \%)\end{array}$ & $\begin{array}{l}34(97.1 \%) \\
39(60 \%) \\
\mathrm{P}=0.04\end{array}$ & $\begin{array}{l}25(71.4 \%) \\
37(56.9 \%) \\
\mathrm{P}=0.4\end{array}$ & $\begin{array}{l}6(17.1 \%) \\
41(63 \%) \\
P=0.005\end{array}$ \\
\hline $\begin{array}{l}\text { COX-2 } \\
\text { Negative } \\
\text { Positive }\end{array}$ & $\begin{array}{l}26(96.2 \%) \\
39(53.4 \%) \\
\mathrm{P}=0.04\end{array}$ & $\begin{array}{l}0(0 \%) \\
73(100 \%)\end{array}$ & $\begin{array}{l}13(48.1 \%) \\
49(67.1 \%) \\
\mathrm{P}=0.3\end{array}$ & $\begin{array}{l}24(88.8 \%) \\
23(31.5 \%) \\
\mathrm{P}=0.004\end{array}$ \\
\hline $\begin{array}{l}\text { DNA ploidy } \\
\text { Diploid } \\
\text { Aneuploid }\end{array}$ & $\begin{array}{l}28(90.3 \%) \\
37(59.6 \%) \\
\mathrm{P}=0.2\end{array}$ & $\begin{array}{l}24(77.4 \%) \\
49(79 \%) \\
\mathrm{P}=0.9\end{array}$ & $\begin{array}{l}0(0 \%) \\
62(100 \%)\end{array}$ & $\begin{array}{l}7(22.5 \%) \\
40(64.5 \%) \\
\mathrm{P}=0.02\end{array}$ \\
\hline $\begin{array}{l}\text { SPF } \\
\leq 18.3 \% \\
>18.3 \%\end{array}$ & $\begin{array}{l}24(45.2 \%) \\
41(87.2 \%) \\
\mathrm{P}=0.04\end{array}$ & $\begin{array}{l}50(94.3 \%) \\
23(48.9 \%) \\
\mathrm{P}=0.04\end{array}$ & $\begin{array}{l}22(41.5 \%) \\
40(85.1 \%) \\
\mathrm{P}=0.02\end{array}$ & $\begin{array}{l}0(0 \%) \\
47(100 \%)\end{array}$ \\
\hline
\end{tabular}


There was also associations between the clinicopathological variables and the number of markers expressed by each carcinoma (Table 4). The expression of more markers was positively correlated with lymph nodes involvement $(\mathrm{P}=$ $0.04)$ and advanced stage disease $(\mathrm{P}=0.001)$.

Table 4:- Number of tumor markers expressed by colorectal carcinomas in relation to clinicopathological variables.

\begin{tabular}{|c|c|c|c|c|}
\hline \multirow[b]{2}{*}{ Variable } & \multicolumn{4}{|c|}{$\begin{array}{c}\text { Expression of survivin, COX-2, DNA aneuploidy and high SFP } \\
\text { Number of tissues (percentage \%) }\end{array}$} \\
\hline & $4(-)$ & $1(+)$ & 2or3or4(+) & $\mathrm{P}$ value \\
\hline $\begin{array}{l}\text { Gender } \\
\text { Male } \\
\text { Female }\end{array}$ & $\begin{array}{l}10(14.3) \\
9(30)\end{array}$ & $\begin{array}{l}20(28.6) \\
10(33.3)\end{array}$ & $\begin{array}{l}40(57.1) \\
11(36.7)\end{array}$ & 0.09 \\
\hline $\begin{array}{l}\text { Age } \\
<65 \text { years } \\
\geq 65 \text { years }\end{array}$ & $\begin{array}{l}11(22.4) \\
8(15.7)\end{array}$ & $\begin{array}{l}17(34.7) \\
13(25.5)\end{array}$ & $\begin{array}{l}21(42.9) \\
30(58.8)\end{array}$ & 0.2 \\
\hline $\begin{array}{l}\text { LN involvement } \\
\text { No } \\
\text { Yes }\end{array}$ & $\begin{array}{l}12(21.8) \\
7(15.6)\end{array}$ & $\begin{array}{l}21(38.2) \\
9(20)\end{array}$ & $\begin{array}{l}22(40) \\
29(64.4)\end{array}$ & 0.04 \\
\hline $\begin{array}{l}\text { Distant metastasis } \\
\text { No } \\
\text { Yes }\end{array}$ & $\begin{array}{l}14(20.6) \\
5(15.6)\end{array}$ & $\begin{array}{l}18(26.5) \\
12(37.5)\end{array}$ & $\begin{array}{l}36(52.9) \\
15(46.9)\end{array}$ & 0.5 \\
\hline $\begin{array}{l}\text { Dukes' stage } \\
\text { A, B } \\
\text { C, D }\end{array}$ & $\begin{array}{l}13(27.7) \\
6(11.3)\end{array}$ & $\begin{array}{l}19(40.4) \\
11(20.8)\end{array}$ & $\begin{array}{l}15(31.9) \\
36(67.9)\end{array}$ & 0.001 \\
\hline $\begin{array}{l}\text { Histological grade } \\
\text { I, II } \\
\text { III }\end{array}$ & $\begin{array}{l}12(16.9) \\
7(24.1)\end{array}$ & $\begin{array}{l}22(30.9) \\
8(27.6)\end{array}$ & $\begin{array}{l}37(52.2) \\
14(48.3)\end{array}$ & 0.7 \\
\hline $\begin{array}{l}\text { Localization } \\
\text { Proximal tumors } \\
\text { Distal tumors }\end{array}$ & $\begin{array}{l}9(29) \\
10(14.5)\end{array}$ & $\begin{array}{l}10(32.3) \\
20(28.9)\end{array}$ & $\begin{array}{l}12(38.7) \\
39(56.6)\end{array}$ & 0.1 \\
\hline $\begin{array}{l}\text { Recurrence } \\
\text { Yes } \\
\text { No } \\
\text { Unknown }\end{array}$ & $\begin{array}{l}9(25) \\
8(16.3) \\
2(13.3)\end{array}$ & $\begin{array}{l}13(36.1) \\
10(20.4) \\
7(46.7)\end{array}$ & $\begin{array}{l}14(38.9) \\
31(63.3) \\
6(40)\end{array}$ & 0.1 \\
\hline
\end{tabular}

\section{Discussion:-}

In the present research, the prognostic significance of the result of immunohistochemical staining of survivin and COX-2, DNA ploidy and SPF in colorectal cancer tissues was studied by associations with the clinicopathological variables of colorectal cancer patients. Our analysis revealed that: (I) Expression of three of the four markers (expression of COX-2 with DNA aneuploidy and high SPF) was independently associated with lymph nodes involvement and Dukes' stage whereas one or two markers were also associated with histological grade, tumor recurrence and tumor localization. Furthermore, some of the clinicopathological variables were also associated with the number of the expressed markers by each neoplasm, the more expression of markers associated with lymph nodes involvement and advanced Dukes' stage. (II) There was association between high SPF and survivin, COX-2 and DNA aneuploidy. In addition, there was also association among the immunoexpression of survivin and COX-2, probably indicating that they might have a common molecular pathway in the carcinogenetic process.

The prognostic value of survivin, COX-2, DNA ploidy and SPF in colorectal adenocarcinomas patients had been presented in many previous researches. However, in this study we attempted to evaluate the prognostic value of their co-expression score. 
In our analysis, Survivin expression was detected in $65 \%$ of the colorectal carcinomas, mainly cytoplasmic within the tumors with no staining in normal colonic epithelium, which is generally in agreement with previous reports, Kawasaki et al. [27], Suga et al.[28] and Sarela et al.[29] stated that survivin staining was observed in the majority of colorectal carcinomas included in their studies. Survivin immnunoexpression was non correlated with any of the examined histopathological variables of colorectal carcinomas, and this result is in concordance with previous related studies [27, 29]. In contrast to our finding, others found that survivin expression is significantly associated with the histological differentiation of colorectal carcinoma [30, 31]. This different reports may be explained by using different primary antibody clone, different immunohistochemical technique and different method in assessments of marker staining.

In our series, $73 \%$ of the colorectal carcinoma expressed COX-2 with immunostaining pattern, predominantly cytoplasmic within the cells of the tumors. The non-neoplastic colonic mucosa nearby to the carcinomas displayed no immunostaining for $\mathrm{COX} 2$, which is in alignment with previous studies [32-34]. We found that COX-2 overexpression, though not correlated with the other clinicopathological features, was significantly associated with Dukes' stage $(\mathrm{P}=0.03)$, lymph node positivity $(\mathrm{P}=0.04)$, and recurrence $(\mathrm{P}=0.02)$. These observations are in concordance with previous studies [35, 36].

In our study, we found that $62 \%(62 / 100)$ of carcinomas had an aneuploid DNA content, this is in agreement with others [37-39]. In both our study and some previous studies [39, 40], a significant association between DNA ploidy and lymph nodes involvement $(\mathrm{P}=0.02)$, Dukes' stage $(\mathrm{P}=0.01)$, histological grade $(\mathrm{P}=0.03)$, and tumor localization $(\mathrm{P}=0.03)$, were found. Finally, similar to previous reports $[38,40]$, DNA ploidy in our series was not related to other clinicopathologic parameters.

In our study, we found the median SPF of the whole series to be 18.3\%, which is similar to findings of others [39]. We also detected a statistically significant correlation among SPF and lymph nodes involvement $(\mathrm{P}=0.03)$, Dukes' stage $(\mathrm{P}=0.04)$, and tumor location $(\mathrm{P}=0.03)$, which is in agreement with others [40].

Regarding the markers co-expression in our investigations, high SPF showed statistically significant association with DNA ploidy $(\mathrm{P}=0.02)$, that is similar previous reports [39, 40]. In addition, there is highly significant association between survivin and high SPF $(\mathrm{P}=0.005)$, a result that agree with Ito et al., [41] who reported that survivin expression strongly associated with the proliferation index and overexpression of survivin lead to an increase in the SPF in human hepatocellular carcinoma. In addition, Kawasaki et al., [42], found that survivin immunoexpression was positively associated with the labelling index of Ki-67 in colorectal cancer. Moreover, Sarela et al., [43], reported that there was positive significant linear correlation among survivin final scores and proliferative index $(\mathrm{P}=0.001)$ in pancreatic cancers.

Regarding COX-2 expression in our series, we found statistically significant association among COX-2 and high $\mathrm{SPF}(\mathrm{P}=0.004)$, a result that come to an agreement with Mrena et al., [44] who informed that the expression of COX-2 was associated with the labelling index of Ki-67 ( $\mathrm{p}=0.013)$ and SPF $(\mathrm{p}<0.0001)$ in gastric cancer. Moreover, Yamagishi et al., [45], told that the expression of COX-2 was correlated with the labelling index of Ki67 in human advanced gastric cancer.

There was also association between survivin expressing with COX-2 $(\mathrm{P}=0.04)$ in our study. Similar finding in gastric cancer have been published by $\mathrm{Yu}$ et al., [46], where association between survivin and COX-2 overexpression was detected at both mRNA $(\mathrm{P}=0.001)$ and protein levels $(\mathrm{P}=0.041)$. Also, our analysis were in agreement with findings of Barnes et al., [47], indicating that the presence of cytoplasmic survivin correlates with the expression of COX-2 in mammary adenocarcinoma. Yang et al., [48], stated that COX-2 expression showed significantly strong correlation with Survivin $(r=0.659, \mathrm{P}<0.001)$ in hepatocellular carcinoma.

In conclusion, we displayed that the co-expression score of survivin, COX-2, DNA aneuploidy and high SPF in colorectal cancer tissues correlates significantly with the poor prognosis of patients with colorectal adenocarcinomas and might be of clinical routine. These results may help in understanding the carcinogenesis of colorectal carcinomas and help the advance of therapeutic strategies like suppression of COX-2 or survivin silencing. 


\section{References:-}

1. Friedlich MS, Stern HS. Primary prevention: what can you tell your patient? Surg Oncol Clin N Am 2000; 9:655-60; discussion 61-3.

2. Fearon ER, Vogelstein B. A genetic model for colorectal tumorigenesis. Cell 1990; 61:759-67.

3. Boo YJ, Park JM, Kim J, Chae YS, Min BW, Um JW, Moon HY. L1 expression as a marker for poor prognosis, tumor progression, and short survival in patients with colorectal cancer. Ann Surg Oncol 2007; 14:1703-11.

4. Feezor RJ, Copeland EM, 3rd, Hochwald SN. Significance of micrometastases in colorectal cancer. Ann Surg Oncol 2002; 9:944-53.

5. Soumaoro LT, Uetake H, Higuchi T, Takagi Y, Enomoto M, and Sugihara K. Cyclooxygenase-2 Expression: A Significant Prognostic Indicator for Patients with Colorectal Cancer. Clinical Cancer Research 2004; 10: 84658471.

6. Salzano G, Riehle R, Navarro G, Perche F, De Rosa G, Torchilin VP. Polymeric micelles containing reversibly phospholipid-modified anti-survivin siRNA: a promising strategy to overcome drug resistance in cancer, Cancer Lett. 2014 Feb 28;343(2):224-231

7. Wang J, Li Z, Lin Z, Zhao B, Wang Y, Peng R, Wang M, Lu C, Shi G, Shen Y. 17-DMCHAG, a new geldanamycin derivative, inhibits prostate cancer cells through Hsp90 inhibition and survivin downregulation, Cancer Lett. 2015 Jun 28; 362(1):83-96.

8. Athanasoula KCh, Gogas H, Polonifi K, Vaiopoulos AG, Polyzos A, Mantzourani M. Survivin beyond physiology: orchestration of multistep carcinogenesis and therapeutic potentials, Cancer Lett. 2014 Jun 1;347(2):175-182

9. Qiu Y, Li X, Yi B, Zheng J, Peng Z, Zhang Z, Wu M, Shen F, Su C. Protein phosphatase PHLPP induces cell apoptosis and exerts anticancer activity by inhibiting survivin phosphorylation and nuclear export in gallbladder cancer, Oncotarget 2015, 6(22):19148-19162.

10. Pennati M1, Folini M, Zaffaroni N. Targeting survivin in cancer therapy, Expert Opin. Ther. Targets 12 (2008) 463-476.

11. Fux R, Schwab M, Thon KP, Gleiter CH, Fritz P. Cyclooxygenase-2 Expression in Human Colorectal Cancer Is Unrelated to Overall Patient Survival. Clin Cancer Res. 2005 Jul 1; 11(13):4754-60.

12. Dario C. Altieri. Targeting survivin in cancer, Cancer Lett. 2013 May 28; 332(2): 225-228.

13. de Leval X1, Delarge J, Somers F, de Tullio P, Henrotin Y, Pirotte B, Dogné JM. Recent advances in inducible cyclooxygenase (COX-2) inhibition. Curr Med Chem 2000; 7:1041-62.

14. Prescott SM, Fitzpatrick FA. Cyclooxygenase-2 and carcinogenesis. Biochim Biophys Acta 2000; 1470:M6978.

15. Sano H, Kawahito Y, Wilder RL, Hashiramoto A, Mukai S, Asai K, Kimura S, Kato H, Kondo M and Hla T. Expression of cyclooxygenase-1 and -2 in human colorectal cancer. Cancer Res 1995; 55: 3785-3789

16. Kargman SL, O'Neill GP, Vickers PJ, Evans JF, Mancini JA and Jothy S. Expression of prostaglandin G/H synthase-1 and -2 protein in human colon cancer. Cancer Res 1995; 55: 2556-2559.

17. Kawamori T, Rao CV, Seibert K and Reddy BS. Chemopreventive activity of celecoxib, a specific cyclooxygenase-2 inhibitor, against colon carcinogenesis. Cancer Res 1998; 58: 409-412

18. Salud A, Porcel JM, Raikundalia B, Camplejohn RS and Taub NA. Prognostic Significance of DNA Ploidy, SPhase Fraction, and P-Glycoprotein Expression in Colorectal Cancer. Journal of Surgical Oncology 1999;72:167-174

19. Quirke P, Dixon MF, Clayden AD, Durdey P, Dyson JE, Williams NS, Bird CC .: Prognostic significance of DNA aneuploidy and cell proliferation in rectal adenocarcinomas. J Pathol 1987; 151:285-291.

20. Lanza G, Gafà R, Santini A, Maestri I, Dubini A, Gilli G, Cavazzini L. Prognostic significance of DNA ploidy in patients with stage II and stage III colon carcinoma. A prospective flow cytometric study. Cancer 1998; $82: 49-59$.

21. Sarela AI, Macadam RCA, Farmery SM, Markham AF, Guillou PJ. Expression of the anti-apoptosis gene, Survivin, predicts death from recurrent colorectal carcinoma. Gut 2000; 46:645-650.

22. Lu C-D, Altieri DC, Tanigawa N. Expression of a novel antiapoptosis gene, survivin, correlated with tumour cell apoptosis and p53 accumulation in gastric carcinomas. Cancer Res 1998; 58: 1808-12.

23. Sarela AI, Scott N, Ramsdale J, Markham AF, Guillou PJ. Immunohistochemical Detection of the AntiApoptosis Protein, Survivin, Predicts Survival After Curative Resection of Stage II Colorectal Carcinomas. Annals of Surgical Oncology 2001; 8(4):305-310 
24. Masunaga R, Kohno H, Dhar DK, Ohno S, Shibakita M, Kinugasa S, Yoshimura H, Tachibana M, Kubota H, Nagasue N. Cyclooxygenase-2 expression correlates with tumor neovascularization and prognosis in human colorectal carcinoma patients. Clin Cancer Res. 2000 Oct; 6 (10):4064-8.

25. Hedley DW, Friedlander ML, Taylor IW, Rugg CA, Musgrove EA: Method for analysis of cellular DNA content of paraffin embedded pathological material using flow cytometry. J Histochem Cytochem 1983; 31: 1333-1335.

26. Taylor SR, Zachariah S, Chakraborty S, Overstreet J, Ramzy L, Mody DR. Ploidy studies by image analysis on fine needle aspirates of the breast. Acta Cytol 1993; 37:923-928.

27. Kawasaki H, Altieri DC, Lu CD, Toyoda M, Tenjo T, Tanigawa N. Inhibition of apoptosis by survivin predicts shorter survival rates in colorectal cancer. Cancer Res 1998; 58:5071-4.

28. Suga K, Yamamoto T, Yamada Y, et al. Correlation between transcriptional expression of survivin isoforms and clinicopathological findings in human colorectal carcinomas. Oncol Rep. 2005; 13:891-897.

29. Sarela, AI, Scott, N, Ramsdale J, Markham AF, and Guillou PJ. Immunohistochemical Detection of the AntiApoptosis Protein, Survivin, Predicts Survival After Curative Resection of Stage II Colorectal Carcinomas. Annals of Surgical Oncology, 2001:8(4):305-310.

30. Kalliakmanis JG, Kouvidou Ch, Latoufis C, Kouvatseas G, Anagnostakis D, Papatheodoridis G, Koskinas J, Archimandritis A. Survivin Expression in Colorectal Carcinomas: Correlations with Clinicopathological Parameters and Survival. Dig Dis Sci (2010) 55:2958-2964.

31. Endo T, Abe S, Seidlar HB, et al. Expression of IAP family proteins in colon cancers from patients with different age groups. Cancer Immunol Immunother. 2004; 53:770-776.

32. Al-Maghrabi J, Buhmeida A, Emam E, Syrjanen K, Sibiany A, Al-Qahtani M and Mahmoud Al-Ahwal: Cyclooxygenase-2 expression as a predictor of outcome in colorectal carcinoma. World J Gastroenterol 2012. 2012 Apr 21; 18(15): 1793-1799.

33. Joo YE, Kim HS, Min SW, Lee WS, Park CH, Park CS, Choi SK, Rew JS and Kim SJ: Expression of cyclooxygenase-2 protein in colorectal carcinomas. Int J Gastrointest Cancer 2002: 31: 147-154.

34. Elzagheid A, Emaetig F, Alkikhia L, Buhmeida A, Syrjänen K, El- Faitori O, Latto M, Collan Y, Pyrhönen S. High cyclooxygenase-2 expression is associated with advanced stages in colorectal cancer. Anticancer Res 2013; 33: 3137-3143.

35. Soumaoro LT, Uetake H, Higuchi T, Takagi Y, Enomoto M, Sugihara K: Cyclooxygenase-2 expression: a significant prognostic indicator for patients with colorectal cancer. Clin Cancer Res 2004;10: 8465-8471,.

36. Sheehan KM, Sheahan K, O’Donoghue DP, et al. The relationship between cyclooxygenase-2 expression and colorectal cancer. JAMA 1999; 6:282:1254-7.

37. Dean PA, Vernava AM III. Flow cytometric analysis of DNA content in colorectal carcinoma. Dis Colon Rectum 1992; 35:95- 102.

38. Pinto AE, Chaves P, Fidalgo P, et al. Flow cytometric DNA ploidy and S-phase fraction correlate with histopathologic indicators of tumor behavior in colorectal carcinoma. Dis Colon Rectum 1997; 40:411-419.

39. Bazan V1, Migliavacca M, Zanna I, Tubiolo C, Corsale S, Calò V, Amato A, Cammareri P, Latteri F, Grassi N, Fulfaro F, Porcasi R, Morello V, Nuara RB, Dardanoni G, Salerno S, Valerio MR, Dusonchet L, Gerbino A, Gebbia N, Tomasino RM, Russo A. DNA Ploidy and S-phase fraction, but not p53 or NM23-H1 expression, predict outcome in colorectal cancer patients. Result of a 5-year prospective study. J Cancer Res Clin Oncol (2002) 128: 650-658.

40. Salud A, Porcel JM, Raikundalia B, Camplejohn RS, Taub NA. Prognostic significance of DNA ploidy, Sphase fraction, and P-glycoprotein expression in colorectal cancer. J Surg Oncol 1999; 72:167-174

41. Ito T1, Shiraki K, Sugimoto K, Yamanaka T, Fujikawa K, Ito M, Takase K, Moriyama M, Kawano H, Hayashida M, Nakano T, Suzuki A. Survivin promotes cell proliferation in human hepatocellular carcinoma. Hepatology. 2000 May; 31(5):1080-5.

42. Kawasaki H1, Toyoda M, Shinohara H, Okuda J, Watanabe I, Yamamoto T, Tanaka K, Tenjo T, Tanigawa N. Expression of survivin correlates with apoptosis, proliferation, and angiogenesis during human colorectal tumorigenesis. Cancer. 2001 Jun 1; 91(11):2026-32.

43. Sarela AI1, Verbeke CS, Ramsdale J, Davies CL, Markham AF, Guillou PJ. Expression of survivin, a novel inhibitor of apoptosis and cell cycle regulatory protein, in pancreatic adenocarcinoma. Br J Cancer. 2002 Mar $18 ; 86(6): 886-92$.

44. Mrena J1, Wiksten JP, Kokkola A, Nordling S, Ristimäki A, Haglund C. COX-2 is associated with proliferation and apoptosis markers and serves as an independent prognostic factor in gastric cancer. Tumour Biol. 2010 Jan; 31(1):1-7. doi: 10.1007/s13277-009-0001-4. Epub 2009 Dec 18. 
45. Yamagishi M1, Noda M, Tatsumi Y, Mukaisho K, Mitsufuji S, Sugihara H, Okanoue T, Hattori T. Correlation between cyclooxygenase-2, proliferative activity, and mucin phenotype in human advanced gastric cancer. J Gastroenterol. 2004 Dec; 39(12):1143-9.

46. Yu J1, Leung WK, Ebert MP, Ng EK, Go MY, Wang HB, Chung SC, Malfertheiner P, Sung JJ. Increased expression of survivin in gastric cancer patients and in first degree relatives. Br J Cancer. 2002 Jul 1;87(1):91-7.

47. Barnes N1, Haywood P, Flint P, Knox WF, Bundred NJ. Survivin expression in in situ and invasive breast cancer relates to COX-2 expression and DCIS recurrence. Br J Cancer. 2006 Jan 30; 94(2):253-8.

48. Yang Y1, Zhu J, Gou H, Cao D, Jiang M, Hou M. Clinical significance of Cox-2, Survivin and Bcl-2 expression in hepatocellular carcinoma (HCC). Med Oncol (2011) 28:796-803 